\title{
Reflection of Liberal Values in the Georgian Press in 1918-1921
}

\author{
Manana Shamilishvili \\ IvaneJavakhishvili Tbilisi State University, Tbilisi, Georgia \\ Mari Tsereteli \\ IvaneJavakhishvili Tbilisi State University, Tbilisi, Georgia
}

\begin{abstract}
This study deals with the values and orientation of Georgian social and political publications in the times of the Georgian Democratic Republic (1918-1921). It also shows how the press of that time reflected the idea of "Georgian Europeanism" based on liberal values that took shape as an anti-colonial concept in the journalism of the late 19th century. The opposed dominant ideological projects of that era comprised on the one hand, National Democratic and Socialist Federalist parties that aspired to preserve national identity and carry out changes and on the other hand, ruling Social Democrats (who initially neglected national identity, but later shared the idea). This opposition was clearly reflected in the media discourse of that time, which implied the following rights based on the principles of classical liberalism: freedom of conscience and expression, rule of law, personal independence, and individual rights. Other elements were added to this list later. The issue of religious tolerance also became topical. Journalist texts of the period reflected and rationalised the values recognised in today's democratic and liberal communities. The research was carried out in the archives of the periodicals of the aforementioned period (newspapers Sakhalkho Sakme, Sakartvelo, Ertoba, and Sakartvelos Respublika) by means of systematising and classifying retrieved materials and making a substantive and varietal analysis of individual media texts.
\end{abstract}

Keywords: Georgian journalism, the Georgian Party Press in 1918-1921, the liberal values, the idea of Georgian Europeanism

\section{Introduction}

The content of the matter under inquiry is multifaceted and problematic. It is very important even today to show the peculiarities of periodicals that appeared in the years of the first independent Georgian republic and the media environment of that time in general, because it is absolutely impossible to make any research in contemporary media and understand their democratic essence without taking into account the classical experience of Georgian journalism throughout its history. The period starting from the 1860s up to 1921 is regarded as a single process of the development of Georgian democratic journalism and its aspiration towards liberal values, which shaped a free and pluralist media environment during the short period of independence.

Observations of the media environment of the first Georgian republic and reflection of its values should be viewed within the context of cultural transmission. Of course, this does not imply a framework that could directly be adjusted to the modern objectives of journalism. The transmission of culture is a process that is in harmony with its development, which helps to maintain major values in time and space (Tsereteli, 2014, p. 342). 
The coexistence of parties legalised in the democratic republic in 1918-1921, their involvement in the governance of the country, and the equality of their rights determined freedom of press and created an unprecedented pluralist environment, where the media existed during the years of independence.

The attempts of the press of that time to explain the essence and importance of civil freedoms to the public implied the following dimensions of rights based on the principles of classical liberalism: freedom of conscience and expression, rule of law, personal independence, and individual rights. It was the idea of "Georgian Europeanism" based on liberal values that took shape as an anti-colonial concept in the journalism of the late 19th century that became the reference point for the values of the press in 1918-1921.

Observations of newspapers and magazines of the years of independence clearly show peculiarities of the era and the whole spectrum of difficulties that interested the Georgian and global communities in the period under inquiry and ultimately created the "agenda" of the media, influencing their profiles and content.

\section{Proto-Experience of the Research}

The period under research coincides with the so-called first lengthy "wave" of democratisation that continued from 1828 to 1926 and lasted for more than a century (Haerpfer, Bernhagen, Inglehart, \& Welzel 2009a, pp. 41-55). However, it was followed by the first reverse "wave" in 1922-1942. In general, political analysts use the term "wave" to denote the global process of democratization. The aforementioned chronological classification belongs to well-known American scientist Samuel Huntington, who identified three major "waves" of democratisation and two reverse "waves". The period we are going to look into belongs to the chronological zone of the first lengthy "wave" and is marked by major upheavals and a high speed of changes. This was followed by an increase in the level of education, urbanisation, and technological progress. All these factors facilitated the development of communications.

The aforementioned situation created favourable conditions for the opinion that the large-scale processes unfolding in the world were signs of the "first" globalization, whose initial stage coincided with the period of the establishment of democratic values in Georgian journalism, encompassing also the years of the first independent republic. This process is also referred to as the process of "failed" globalization. According to Kakha Katsitadze (2007), the process of globalization would have been a success had there been no World War I (pp. 258-260).

It should also be said here that the pluralist media model of the 21 st century that is very far removed from that in the Soviet times, is qualitatively closest to the democratic media model of independent Georgia in 1918-1921.

Most works on the years of independence of Georgia belong to the fields of historiography and political science. As regards scientific research in the media environment, it is noteworthy that specific issues have mostly been studied in individual works from a certain angle, but no comprehensive research has effectively been done in the press of that period and problems of the 20th century journalism, and values promoted by the press have never been analyzed.

The main specific feature of the Georgian press of the period under research is manifested through the specific features of the era and the dominance of the press affiliated to parties. Periodicals of the first quarter of the 20th century should be considered precisely from the angle of conceptual contradictions. The leaders of the Georgian periodicals revived in this era-journalists affiliated to parties and first and foremost prominent commentators and authors (M. Javakhishvili, T. Tabidze, G. Kikodze, V. Barnov, S. Pirtskhalava, R. 
Gabashvili, Sh. Amirejibi, I. Chkonia, G. Veshapeli, A. Tsuladze, and others)—spared no effort to openly speak about vital problems of the country that had found itself in a dire situation.

The critical situation that had taken shape facilitated the development of the press. The acute political situation sobered up journalists and forced them to do all they could. Despite their affiliation to specific parties, newspapers managed to reflect the reality in an unbiased manner and bring to light different problems of public and political life.

Newspapers were selected for this study on the basis of how they reflected the main conceptual trends, the number of copies circulated, periodicity, duration, broadness of profile, variety of journalistic forms, and high creative potential. All available issues of these newspapers were considered in this study.

\section{Theoretical Frameworks and Methodology of the Study}

The methodology of research is based on familiarizing ourselves with relevant sources, finding necessary materials and systematising and processing them. The approach to the problem is comprehensive with the context being taken into account. The method of comparative analysis will also be used to study and compare the peculiarities of the reflection of liberal values in specific publications, which is supposed to enable a modern reception of one of the most interesting and complicated periods in the history of Georgian journalism.

In this research, we are guided by the polarized pluralist media model of Daniel Hallin and Paolo Mancini (Hallin \& Mancini, 2004, pp. 89-143). Although this concept focuses on processes that unfolded later than the period under discussion, we can successfully use it to make research in the peculiarities of the media of any other period.

Prominent specialists in the comparative analysis of national media systems, Paolo Mancini and Daniel Hallin, developed a methodology, identifying three kinds of media systems, including the aforementioned polarized pluralist model, which is also called the Mediterranean model (France, Greece, Portugal, Italy, and Spain). The authors made the classification of media systems based on the following criteria: Peculiarities of the development of the press in countries, political parallelism, the level of professionalism of journalists, and the government's role in the information system. Every criterion is important to identify the peculiarities of the media of specific countries. The criterion of political parallelism is particularly important for us, as it clarifies the nature and extent of relations between the media and political structures. It is an important marker that can show how an information system reflects major political differences in society.

Given this, in order to analyse publications of the period under research, we can refer to the model of Mediterranean countries. In this model, a country may have a pluralist environment and a variety of ideas fully reflected by the media that offer a forum to society for latter's fuller involvement in political processes, but due to the situation that is marked with sharp ideological confrontation, the media environment is polarised. In such conditions, every influential media outlet is trying to promote a concrete political party, effectively serving the interests of one specific ideology.

The primary research provides grounds for formulating the following questions: (1) What democratic values did the periodicals under research serve and promote? (2) What major features created the pluralist media environment of that time and what values shaped a common platform for the ideologically polarised press; and (3) What was the impact of the trend of Europeanisation on journalist products of the time under research? 
Based on these questions, a strategy of the research was elaborated, which made it possible to presume that ideologically opposed publications affiliated to different parties in 1918-1921 were united by their loyalty to democratic values expressed in their aspiration towards Europeanisation as a strategic universalism. Political and cultural Europeanism was a unifying idea for them and they never discussed Georgia's future as a state without implying this idea. To make an in-depth analysis of the problems under discussion, we identified several directions of the research.

\section{Criticism of Bolshevism}

It is known that Bolsheviks came to power in Russia after the coup on 7 November (old style 25 October) 1917. Georgian poet and commentator Titsian Tabidze (1895-1937) said:

The fire has not yet faded away, but the future is aggravated by phantasmagoria and nightmares. The fatal image of Lenin, who scragged Russia's future and staged a carnival of imps with his crazy hand, can be seen from burnt Russian steppes through snowy smoke. (Tabidze, 2000, pp. 452-453)

Georgia selflessly plunged into this "phantasmagoria", which was due to changes in the processes unfolding at an accelerated pace - the Transcaucasian Commissariat (Sejm), social reforms, and the declaration of independence, the fall of Batumi and the invasion of askers, intensified domestic confrontation and imminence of war, demonstrations of Georgian modernists against pacifism and their irredentist demands of regaining lost territories, conflicts with Dashnak Armenia, Denikin, and Musavat Azerbaijan, and in addition to all this, confrontation and differentiation between parties, creation of new groupings and unions, and so forth.

Previously, liberal values could be seen in the shape of generalized concepts, but later, they moved to the format of constant discussions between parties, a new trend that emerged due to the so-called Bolshevik coup in 1917. There were three publications with different ideologies in that period: Ertoba (1917-1921), Sakartvelo (1915-1921), and Sakhalkho Sakme (1917-1921) and the so-called government newspaper Sakartvelos Republika, which appeared in 1918-1921, was restored after the Communist rule ended in Georgia in 1990, and continues to appear up to now.

It is noteworthy that the government did not use Sakartvelos Respublika to promote narrow party interests. The newspaper mostly focused on factual reports. It also published government decisions, decrees, appeals, and materials on sessions of the Constituent Assembly, events in individual ministries, and novelties, speeches by government chairman and ministers, and news about developments within the country and abroad. Thematically varied news items were presented in the rubric of Chronicle. Correspondingly, the newspaper effectively carried no analytical journalist materials and it follows that comparatively few materials are available for this research. However, observations of the government's decisions and various democratic legal norms show that the editorial policy of Sakartvelos Respublika reflected the position of the government, which made it an organic part of the pluralist Georgian media environment. Examples quoted below confirm this opinion.

Thus, all the aforementioned publications held one position - the "idea of Europeanisation". From this position, the new political force that had come to power by using violence found itself under constant criticism and it is natural that Bolshevism became the target of the criticism as an inhuman and antidemocratic ideology.

The criticism of Bolsheviks and their publications by the Ertoba newspaper of the Social Democratic Party was sharp and implacable. Former fellow party members were accused of pseudo-socialism and treason of democracy, violations of human rights, violence, prohibition of freedom of speech and freedom of press, 
intolerance towards opposing views, and violations of property rights. Such attitudes were rife in publications in 1917-1918. The newspaper familiarised leaders in an amazingly prompt manner with events unfolding in Russia, the Caucasus, Georgia, and the whole world. Theoretical articles and commentaries were also published. In this regard, it would be interesting to note and article headlined The Ideals of Modern World Capitalism by prominent Social Democrat Kvirileli (the penname of Irakli (Kaki) Tsereteli-1881-1959) that was published in Ertobain 1918 (Ertoba, 1918, No. 6-7, p. 3).

Certain materials created a journalistic and documentary narrative about political cataclysms of the era and it is quite logical that most of them were about processes under way in Russia. The main players in the new political scene-Lenin, Trotsky, and then People's Commissar for Nationalities' Affairs in the Soviet Government, Joseph Stalin appeared in various texts in connection with unfolding events. Bolsheviks have trampled the interests of democracy and at the same time, they are saying: "We are the saviours of people". Our readers probably remember that the provisional government regarded such important and complicated issues as the problems of land and nationalities, as being within the competence of the Constituent Assembly. However, what a nuisance! Bolsheviks are now dominating the centre. Together with other decrees, Minister Jugashvili-Stalin issued a decree that granted nations the right to self-determination. Many nations refused to recognise Lenin's autocracy. For example, Ukraine behaved in that manner, implementing the Bolshevik decree and Bolsheviks themselves started fighting against it later (Ertoba, 1918, No. 6-7, p. 3).

On the basis of numerous materials in the newspapers we have analysed (up to 1,500 publications), we can give answers to problems under research. Ultimately, this is to prove that our supposition is right.

\section{Problems of Women's Emancipation}

The newspapers also published materials reflecting women's problems, including those written by women. It is true that the number of such materials was low, but they were written at quite a professional level and with correct accents and in-depth vision of social and political problems women were facing. Women, who were politically active (for example, Nino Nakashidze, MinadoraToroshelidze, PedosiaJaparidze, and others), usually wrote such materials. Their articles clearly show that they were well-informed on processes linked to gender equality under way throughout the world and objectively assessed the efforts of the new republic aimed at resolving the problems at the legislative level. At the same time, speaking about the problems, they did not shun sharp criticism.

Every newspaper reflected women's problems from their own angle. For example, the feminist narrative in the Ertoba newspaper was marked with revolutionary spirit. It comprised a big amount of information on women's membership of the Social Democratic Party and the creation of their unions and their meetings, assemblies, and rallies held. These kinds of materials were mostly factual and were presented in chronicles of events comprising just a few sentences. Analytical articles were also published and they focused on women's conditions and violations of their rights; the need to get women involved in the legislative and executive branches, the demand that women's opinions be taken into account when adopting laws linked to women, and so forth. Unfortunately, most of these demands were not met in the first republic.

The Ertoba newspaper gave an intensive coverage of the visit of European socialists to Georgia in September 1920. The newspaper published the text of a speech by prominent British politician and journalist Ethel Snowden (1881-1951). Snowden emphasised that Georgian women were active in public life and noted that it was a women's organisation that was the first to meet their delegation with flags in their hands: 
We are happy about the role women are playing in Georgia. Unfortunately, the situation is not yet the same in our country. English women can only elect others, but they cannot be elected. In your country, women are equal to men. (Ertoba, 1920a, No. 153, p. 3) ${ }^{1}$

However, the quoted assessments were exaggerated, which becomes clear due to numerous newspaper materials, which mostly reflect violations of women's rights and disregard for their involvement in the governance of the state. In an article published in Ertoba under the headline of Woman's Voice, the author-Comrade Woman-focused precisely on the fact that women were deprived of any rights. She wrote that the cumbrous experience of the past had set a stamp upon their lifestyle and women's involvement in the public and political life was weak. The author concentrated on women's participation in the local self-government election and protests against the fact that there were very few of them on the list of candidates. A female candidate was only on 17th place and the 8th and 15th places were given to them only after the protest. The article also expressed hope that the Social Democratic Party would take the situation into account in the future and pay more attention to women (Ertoba, 1919, No. 36, p. 3).

The Social Federalist newspaper Sakhalkho Sakme also paid much attention to women's problems. It published news as well as analytical materials. The article "State Building and Georgian Women" by writer Nino Nakashidze is particularly noteworthy in this regard (Sakhalkho Sakme, 1918a, \#360, p. 3). The author discussed major problems women faced and urged the government to resolve them. She demanded women's active involvement in the government's activities and resolution of problems like those of single mothers, prostitution, pregnant women, protection of women's labour, and so forth.

A number of materials published in SakhalkhoSakme were devoted to equal rights for women. The following analytical articles were distinguished by their particularly sharp criticism: Protection of Mothers — unattributed (Sakhalkho Sakme, 1919, No. 704, p. 3), What Do You Want from Women? —signed by Georgian Woman (Sakhalkho Sakme, 1920, No. 821, p. 3), The Role of Georgian Women in Building Their Homeland — signed by Pedosia Japaridze (Sakhalkho Sakme, 1920, No. 947, p. 3; No. 948, p. 4), and others.

The Sakartvelo newspaper took little interest in women's problems. Very few publications on this issue present a stereotype image of women, traditionally praising the beauty of Georgian ladies. For example, one of the publications headlined The Name Day of Writers described a festive event held under the "patronage" of noble women. Writers invited to the dinner elected the most beautiful woman (Sakartvelo, 1920, No. 12, p. 3). The newspaper also published an advertisement of a performance that had a very discriminative and prejudiced title-The Club of Women-haters (Sakartvelo, 1920, No. 11, p. 1). Yet another issue of the newspaper carried a theatre bill advertising a performance named Man and Woman (Sakartvelo, 1918, No. 245, p. 1). Unfortunately, such examples were quite numerous on the pages of the newspaper.

It is noteworthy that all the three publications were more or less interested in feminist issues and problems discussed were almost the same. However, Sakhalkho Sakme was the one that carried most of analytical materials. The aforementioned newspapers acknowledged equality of women and urged them to become involved in the governance of the country more actively. However, the same newspaper materials make it clear that nothing was changing in real life and everything remained on the level of slogans and declarations, which

\footnotetext{
${ }^{1}$ Later, in the 12 October 1920 issue of the Manchester Guardian newspaper, Ethel Snowden published an article on the public and political situation in Georgia headlined "Mrs. Philip Snowden's [Ethel Annakin's] Impression on Georgia-Russia", in which she made the following comments on the young Georgian state: "They [Georgians] have set up what is the most perfect socialism in Europe. [... They]are opposed to Bolshevism in practice and in theory".
} 
points to the fact that there was no readiness for broad public activeness of women and the press, to a certain extent, played a progressive and look-ahead role.

Sexist statements could also be seen on the pages of newspapers. For example, "Zinaida Gippius is an important poet among women. She has a manly mindset and peculiar masculine irony" (Sakartvelo, 1920, No. 92, p. 3). It is also noteworthy that this statement was placed under the Literature and Art rubric. News items about family violence were not rare either. Newspapers published reports on violence against women and murders of wives and such reports often had headlines like Woman Murdered, Wife Killed, Corps of Killed Woman, and so forth. Facts of women's discrimination could also be seen in posters and advertisements the newspapers carried.

Women's activities in arts and literature received a comparatively broad coverage. Newspapers carried poems written by women. For example, Sakhalkho Sakme published lyric poems by Marijan, Sakartvelo published Anastasia Natsvlishvili's poem The Call of Mother, and so forth.

It can be said that the publications under research presented feminist issues in a multifaceted manner. The focus on women's problems and gender equality in general is indicative of the development of democracy in the first republic.

\section{Religious Tolerance}

The problem of religious tolerance was particularly topical in newspaper materials on the elimination of the occupation of south-western Georgia and the problem of national identity in the area. The newspapers also touched on religious tolerance in materials about the regions of Samachablo, Abkhazia, and Hereti (Samachablo-so-called South Ossetia-and Abkhazia are the territories currently occupied by Russia and historic Hereti is now part of Azerbaijan). Such materials were most frequent on the pages of the Sakartvelo newspaper.

The newspapers regularly published reports on the processes under way in south-western Georgia, covering every development taking place around "Muslim" Georgia. Such publications can be united under the name of the Ajaria issue. They described complicated political and economic problems in the region and the unbearable conditions of the population of Ajaria, supporting the idea that the salvation of this ancient region of Georgia was possible only in unity with the rest of the country.

Although the young republic had regulated the problem of religious and ethnic tolerance at all normative and legislative levels, the situation did not nevertheless provide grounds for satisfaction. Facts of the violation of religious rights, wilful behaviour of dishonest bureaucrats, and deliberate attempts of provocateurs, who tried to raise suspicions among Georgian Muslims, motivated residents of the region to distrust the Georgian authorities.

Describing the complicated situation in the Muslim community of Georgia in an article published on 5 August 1920, the Ertoba newspaper offered a classification of groupings opposing the state in Ajaria. The classification was based on the opinions of local residents: (1) The Committee of Young Turks; (2) Azerbaijani agents; (3) Bolsheviks, who spent 27 million roubles; (4) Russian volunteers; (5) The local administration that had no connection with the district; and (6) Elements from outside (Ertoba, 1920b, No. 175, p. 3).

Later, the government carried out some measures to resolve the problems, which can be seen in the report by Petre Geleishvili (1870-1937), a member of the Constituent Assembly, who the government dispatched to Ajaria as their special envoy to study the situation on the spot. ${ }^{2}$ A long list of problems in the report comprises,

\footnotetext{
2 This issue is discussed in detail by S. Dunduain Muslim Georgia and Problems of Civil Integration (Dundua, 2014, pp. 149-154).
} 
among others, the problem of autonomy. It is noteworthy that the report was published on 8 October 1920, a year before the Constitution was adopted. Ajaria was granted autonomy in the constitution of 1921 under Article 107 of Chapter 11- "Muslim Georgia (Batumi region) is granted the right to local autonomous governance".

The publications under research published quite a number of articles on the need to set up an administrative system in Ajaria. This time, we will focus on the material published in the Sakhalkho Sakme newspaper on the visit to the Georgian capital of an Ajarian delegation led by Memed Abashidze (1873-1937), a prominent Georgian figure and commentator, who fell victim to repressions in Syalin's time. The aim of the visit by members of Mejlis (Parliament) to Tbilisi was to negotiate the administrative system of Ajaria with the government. The newspaper of Social Federalists reacted to the visit quicker than others and interviewed the head of the delegation on 30 July 1920. The interview that was presented as a monologue was headlined Conversation with Memed Abashidze. It appeared on the pages of the newspaper on 1 August (Sakhalkho Sakme, 1920, No. 890, p. 2). The interviewee spoke at length on the problems Ajaria was facing and the need for autonomy.

The interview we retrieved in 2002 was unknown to the public at large before. It is interesting also because this journalist genre was a novelty for the press of that time (Shamilishvili, 2002, pp. 144-154). This genre was chosen, because the issue was also specific. This journalist method is efficient for focusing on a topical issue, as it allows conveying sentiments of the masses of people. In this case, the interviewee expressed not only his own opinions, but also the opinions of all Georgian Muslims.

The respondent regarded as reasonable to grant Ajaria the right of autonomous governance. He described this as a measure for the prevention of an exodus of Muslims from Ajaria and noted:

As Minister Ramishvili [Noe Ramishvili (1881-1930), the interior minister in the first democratic republic] told us on behalf of the government, Georgian Muslims are going to have their own Shaykh-ul-Islam [top spiritual leader]. This is a great idea for this state and it will have a good result for Georgia's territorial integrity, because Muslims, who are Georgian citizens, will no longer rely on other Muslim countries. (Sakhalkho Sakme, 1920, No. 890, p. 2)

The quote above shows that the Georgian government legally formalized the rights of Muslim Georgians (and other ethnic and religious minorities), thus facilitating their integration with the rest of Georgian population. However, it nevertheless failed to take efficient measures in this regard, as it did not have sufficient time.

The problem of "Lazistanirredenta" raised in an article by Titsian Tabidze published in the Mtliani Sakartvelo newspaper was linked to the problem of the restoration of Georgia's territorial integrity, which was an important challenge in the years of Georgia's sovereignty. The Social Democratic government tried to resolve most important problems with available political and legal methods.

Titsian Tabidze raised the issue in the editorial headlined For Irredenta published in the Mtliani Sakartvelo newspaper he was publishing. What Tabidze was dreaming about was the idea of one of the ideologists of the Blue Horns ${ }^{3}$ and the founder of futurism, Italian author Marinetti. Under the influence of the

\footnotetext{
${ }^{3}$ The Blue Horns-a group of Georgian symbolist writers (1916-1932). The group published the Tsisperi Kantsebi magazine (1916). Paolo Iashvili was the leader of the group and the editor-in-chief of the magazine. The group comprised well-known Georgian authors G. Robakidze, T. Tabidze, V. Gaprindashvili, N. Mitsishvili, K. Nadiradze, A. Arsenishvili, G. Leonidze, S. Tsirekidze, and others. At the beginning, prominent Georgian poet GalaktionTabidze was also regarded as a member of the Blue Horns, but later, he left the group. Most of the authors fell victim to Stalin's repressions in 1937; Paolo Iashvili committed suicide in the building of the Union of Writers; TitsianTabidze was arrested and disappeared without trace; and Nikolo Mitsishvili was executed.
} 
latter's teaching, whose futurist postulates the Blue Horns had borrowed on a lot of occasions, Tabidze raised the problem of regaining the Georgian territories conquered by the Ottoman Empire. He wrote quite sharply about joining Lazistan and Trabzon to Georgia. The reaction of Georgian officials and the ruling Social Democratic Party was quite strict (a critical response was published in the Ertoba newspaper, which was followed by yet another response in the Sakartvelo newspaper (Sakartvelo, 1920, No. 18; Ertoba, 1920, No. 71). All this ended in the closure of Tabidze's newspaper. ${ }^{4}$

\section{Features of Media Pluralism}

The "common platform" of the ideologically polarised press was expressed first and foremost in the attempts of the government to create an appropriate environment and real conditions for freedom of press and expression. To confirm the aforesaid it would be sufficient to refer to the simultaneous existence of publications affiliated to various parties. Moreover, the fact that even the Bolshevik press was working freely (although this was due to concrete political purposes) is yet another confirmation of the aforesaid. Incidentally, in conditions, where the newly-created republic was involved in the everyday struggle to protect itself, this democratic environment and the pluralism characteristic of Western democracies created an arena enabling hostile publications to carry on permanent and purposeful propaganda against the government, which contributed to a certain extent to the defeat of the new republic and its annexation by Soviet Russia on 25 February 1921.

The factor of editorial freedom should also be mentioned here. Despite the affiliation to specific parties and ideologies, the publications under discussion were tolerant to opposed political forces and published materials reflecting various opinions, which can be regarded as examples of professional solidarity and broad thinking. This can clearly be seen in editorials. We can see such approaches mostly in cases of decisions important for the state and celebrations of important dates. For example, summing up six months of the country's independence, the Social Federalist newspaper Sakhalkho Sak'me assessed in its editorial on 3 December 1918 the speech by Noe Zhordania (1868-1953), a Social Democrat and the chairman of the government of the Democratic Republic of Georgia:

Noe Zhordania was right, when he said that Georgia has always aspired towards Europe and no matter what turn history may take, we will be looking in the direction of Europe and European democracy and Georgia is not going to lose its face and interests on this path. It is this correct, daring, and decisive policy that is the foundation that enables us to declare: We are not afraid of the future! (Sakhalkho Sakme, 1918b, No. 399, p. 1).

Sakartvelos Respublika also served the purpose of uniting the population and raising their awareness of the importance of the state, when the editorial board launched the initiative of collecting donations for needy people and urged others to join the effort: "Citizens! Devastated Meskheti-Javakheti is in need of assistance. Let us lend a helping hand to the desolate region. Fulfil your duty: Help it!" (Sakartvelos Respublika, 1919a, No. 1, p. 2).

It is noteworthy that the official newspaper allowed other publications to use its pages, if the problem discussed was topical and in line with its editorial policy. For example, the newspaper reprinted an editorial headlined In Muslim Georgia from Ganakhlebuli Meskheti (No. 10). The article was about the strategic importance of education for the Georgian government:

\footnotetext{
${ }^{4}$ The aforementioned editorial written by TitsianTabidze and his response to his opponents published in the Sakartvelo newspaper - To the Accomplices of Ertoba-were discussed in detail in Nodar Tabidze's paper The Mtliani Sakartvelo Newspaper (Tabidze, 2004, pp. 105-127).
} 
Schools, reading-rooms, Sunday classes, helping people to emerge from darkness, and sprinkling them from the baptismal font of new life are what can unite Akhaltsikhe and Akhalkalaki with the whole of Georgia. (Sakartvelos Respublika, 1919b, No 100, p. 2)

It should be noted here that the government also aimed at achieving regional peace and ethnic solidarity in the Caucasus, which can easily be seen in publications in newspapers. For example, Sakartvelos Republika published an article headlined Georgia's Greetings to Armenia, expressing satisfaction with the truce Armenia had concluded with the Ottoman Empire:

We believe that the hardest moments of Armenia's tragedy are over. Let the cause of Armenia's independence and statehood be long lived and prosperous. Let the friendship and brotherhood between our genuinely fraternal nations become even firmer. (Sakartvelos Respublika, 1920, No. 200, p. 3)

Such examples make it clear that our ancestors had a good understanding of what genuine patriotism was. They regarded patriotism not as an expression of nationalism or ethnic and cultural supremacy alone, but also as loyalty to the state, which is an exemplary approach for us even now. It can be said that the publications of that time carried the idea of "political patriotism". They had concrete aims and they discussed systems appropriate for the Georgian state. However, at the same time, a kind of "romantic" patriotism can also be clearly seen in them, which is expressed in the apologetic approach to the Motherland.

The media environment created thanks to the efforts by the government also ensured "external" diversity by promoting unimpeded functioning of publications affiliated to various ideologies and ensuring "internal" variety by means of editorial freedom. The aforementioned model was described by prominent researcher Denis McQuailin his Normative Media Theory, where he identified levels of "internal" and "external" diversity of the media, regarding both models legitimate in presenting different views (Haerpfer, Bernhagen, Inglehart, \& Welzel, 2009b, pp. 243-245). Such a principle is characteristic of only the democratic press and the media environment that had taken shape was precisely appropriate for the polarised pluralist media model of Daniel Hallin and Paolo Mancini we chose as a theoretical framework for this work.

\section{New Creative Trends of Media Products}

The varieties and genres of the literary and journalist materials of the publications in the period under research are as follows: (1) News-reports on literary and theatrical life and art in general; (2) Literary criticism reviews and surveys; (3) Opinion-based journalism proper-examples of analytical and art journalism; and (4) Fiction (it is noteworthy that individual publications had their favourite authors - prominent Georgian writers, whose works they used to publish. For example, the Socialist Federalist Sakhalkho Sakme published a lot of works by Konstantine Gamsakhurdia and Ioseb Grishashvili; National Democratic Sakartvelo preferred works by Blue Horns, and Social Democratic Ertoba, as well as Sakhalkho Sakme, was favourable disposed towards Galatkion Tabidze).

Political and artistic products presented within the frames of specific concepts were very helpful to the Georgian public in understanding complicated political processes, raising the awareness of democratic values, and satisfying their spiritual demands. Materials in the publications under discussion clearly reflected the complicated political situation that had taken shape in the young republic. To clarify the essence of the situation, assess it correctly, and draw correct conclusions the publications offered their readers analytical articles. Almost all editorials of all newspapers provided an analysis of concrete problems - key issues of domestic and 
foreign policy. In conditions of the pluralist media environment, texts in the newspapers had the form of dialogue. In order to establish communications with readers, authors increasingly often resorted to "vivacious" journalist forms. The press in the period under research was dominated by everyday news in the shape of short or broadened reports, and readers' letters. The analytical genre was most frequently represented as editorials, essays, articles, reviews, authors' columns, and even portraits.

It is noteworthy that the journalist genres (forms) in the press of that time became creative and flexible in accordance with the demands of the time and materials were presented with various accents. Argument-based analysis, not merely propaganda, factual coverage, polemical style, unrestricted political and geographic informational area, constant communication with readers, and involvement of who are now described as civic authors (workers, teachers, doctors, and others) are all signs characteristic of democratic media and should definitely be regarded as a manifestation of European trends in journalism.

Political analysts of the publications under research (to mention just a few of them, of whom some have pennames that have not been clarified yet: Ireteli, B. Ninidze, M. Tamazashvili, Z. Datiashvili, Sapareli, A. Plebeishvili, D. G.-dze, S. Eliadze, Salakaia, Kakiladze, S. Tskhemliskhideli, Tite Margvelashvili, I. Khananashvili, and others) resorted to various artistic methods to make their works clearer and more convincing and often conveyed the philosophic content of events and concepts by means of proverbial phrases such as "Bolsheviks, the alchemists of revolution", "Lenin and others have forgotten Marxism and are rushing nonstop towards an anarcho-syndicalist utopia, "the government of experiments and fantasies", "sickpeople in revolutionary clothing", "the morality of Russian socialism - this new morality", and so forth.

\section{Conclusions}

Thus, despite differing ideological views and opposed ideas, the press at the beginning of the 20th century made a major contribution to the introduction of liberal and democratic values by creating a pluralist environment, which enabled dissemination of various views.

Observations of the main media outlets of that time (newspapers Ertoba, Sakhalkho Sakme, Sakartvelo, Sakartvelos Respublika) helped to highlight from the philosophic angle the peculiarities of the discourse of political journalism and the reflection in media texts of processes unfolding in the empirical time. The analysis of aforementioned problems enabled us to clearly identify the main vectors of values of the political media of the time. The analysis confirmed our assumption that loyalty to democratic values and cultural and political Europeanism as a unifying idea united the ideologically opposed press outlets of 1918-1921.

\section{References}

Dundua, S. (2014). Muslim Georgians and problems of civil integration. Collection of scientific works of the 2nd international Scientific Conference "Space, Society, Politics". No. 2, Tbilisi, University Publishers, 149-154 (in Georgian). Ertoba. (1918). Ertoba newspaper, No. 6-7. Publication of the Georgian Social Democratic Party, Tbilisi, 3 (in Georgian). Ertoba. (1919). Ertoba newspaper, No. 36. Publication of the Georgian Social Democratic Party, Tbilisi, 3 (in Georgian). Ertoba. (1920a). Ertoba newspaper, No. 153. Publication of the Georgian Social Democratic Party, Tbilisi, 3 (in Georgian). Ertoba. (1920b). Ertoba newspaper, No. 175. Publication of the Georgian Social Democratic Party, Tbilisi, 3 (in Georgian). Haerpfer, Ch. W., Bernhagen, P., Inglehart, R. F., \& Welzel, Ch. (Eds.). (2009a). Democratization. Oxford, University Press. Haerpfer, Ch. W., Bernhagen, P., Inglehart, R. F., \& Welzel, Ch. (Eds.). (2009b). Democratization. Oxford, University Press. Hallin, D. C., \& Mancini, P. (2004). Comparing media systems-Three models of media and politics. Cambridge University Press. Katsitadze, K. (2007). The Era of Ilia and present-day life. Collection of works of the Institute of Georgian Literature published on Ilia Chavchavadze's 170th anniversary: Ilia Chavchavadze 170. Tbilisi, 258-260 (in Georgian). 
Sakartvelo. (1920). Sakartvelo newspaper, No. 92, Tbilisi, 3 (in Georgian).

Sakartvelos Respublika. (1919a). Sakartvelos Respublika newspaper. Government Messenger, No. 1, Tbilisi, 2 (in Georgian).

Sakartvelos Respublika. (1919b). Sakartvelos Respublika newspaper. Government Messenger, No. 100, Tbilisi, 2(in Georgian).

Sakartvelos Respublika. (1920). Sakartvelos Respublika newspaper. Government Messenger, No. 200, Tbilisi, 3(in Georgian).

Sakhalkho Sakme. (1918a). Sakhalkho Sakme newspaper, No. 360, Tbilisi, 3 (in Georgian).

Sakhalkho Sakme. (1918b). Sakhalkho Sakme newspaper, No. 399, Tbilisi,1 (in Georgian).

Sakhalkho Sakme. (1920). Sakhalkho Sakme newspaper, No. 890, Tbilisi, 2 (in Georgian).

Shamilishvili, M. (2002). Unknown Interview on the autonomy of muslim-populated Georgia. Journalist Research Papers, Vol. II, Tbilisi, University Publishers, 144-154 (in Georgian).

Tabidze, N. (2000). Galaktion. Tbilisi, 452-453 (in Georgian).

Tabidze, N. (2004). The Mtliani Sakartvelo Newspaper. Journalist Research Papers, Vol. VI, Tbilisi, 105-127 (in Georgian).

Tsereteli, M. (2014). The democratic values of the modern Georgian media in the context of cultural transmission. In Collection of materials of the 8th international symposium: National Literatures and the Process of Cultural Globalisation. Tbilisi, Institute of Georgian Literature Press, 342 (in Georgian). 